\title{
One last nail in the MAPLEs coffin
}

$\mathrm{C}$ onsider it the final death knell for what were to have been the next generation of medical isotope-producing nuclear reactors in Canada and perhaps, a major blow to the fiscal health of isotope distributor Nordion Inc.

A four-year legal odyssey aimed at restarting the technically plagued, over-budget, overdue and overdesigned Multipurpose Applied Physics Lattice Experiment (MAPLE) reactors ended this week when an arbitration panel denied Nordion's bid to compel Atomic Energy of Canada Ltd. (AECL) to restart the project or provide compensation to the distributor for its part in developing the next-generation reactors.

The federal government and AECL had announced in 2008 that they were discontinuing the MAPLEs project because of persistent technical problems and "economic impediments" (www.cmaj.ca/lookup/doi /10.1503/cmaj.080788). But Nordion insisted that the move violated the terms of a 2006 isotope supply agreement it signed with AECL and demanded compensation for some $\$ 350$ million it had invested in the MAPLEs project.

The two reactors now sit dormant in a nondescript set of concrete buildings in Chalk River, Ontario, near the aging National Research Universal reactor that is currently irradiating uranium targets to produce molybdenum isotopes used in medical imaging facilities around the world. They were to have been the first reactors in the world dedicated exclusively to the production of medical isotopes but during initial testing, failed to perform according to their original specifications and no amount of analysis or technological repair resolved the performance deviations from those expected of the design. Nearly a decade of investigation could not resolve the problem (www.cmaj.ca /lookup/doi/10.1503/cmaj.080320).

Still, Nordion and engineers who had worked on the MAPLE reactors insisted that they could be made to run properly and opted to pursue arbitration in a bid to get the project re-started.

The confidential arbitration panel dismissed that notion. "The majority of medicine procedures performed annually in Canada (www.cmaj.ca/lookup /doi/10.1503/cmaj.109-4217), while Canadian regulators, politicians and isotope distributors have been scrambling to craft a strategy to secure a reliable supply of isotopes once the National Research Universal reactor is shut down for good in 2016 (www.cmaj.ca/lookup/doi /10.1503/cmaj.109-4263).

Whatever the solution, the reality is that per-unit costs will be much higher than those originally conceived for the MAPLEs.

For Nordion, the task will be to find an alternative source of isotope supply and the firm is now considering such options as partnering with reactor operators in Russia, where there remains plenty of capacity to generate medical isotopes. "That partnership is still ongoing," Benjamin says. "We're still in the early stages of testing and evaluation, but we are certainly expecting to have supplemental commercial supply by 2016."

Meanwhile, the arbitrator's ruling was blamed for an immediate decline in Nordion's stock price, although the firm's decision to suspend payment of its quarterly dividends and cancel stock repurchases also contributed to the plunge in Nordion stock from more than $\$ 10$ to $\$ 6.64$.

Benjamin insists that Nordion still treads solid business ground. Less than half the company's revenue comes from isotope redistribution, and other lines of business include sterilization technologies and specialized radiation therapies for cancer that are unaffected by the vagaries of molybdenum processing, she says. "It's a disappointing outcome but we really want to keep ourselves and our team focused on making sure that we continue with our business objectives and deliver on our strategic priorities that we have." - Tim Lougheed, Ottawa, Ont.

CMAJ 2012. DOI:10.1503/cmaj.109-4299 